\title{
Reformist Reforms, Non-Reformist Reforms and Global Justice: Activist, NGO and Intellectual Challenges in the World Social Forum
}

Bond

Follow this and additional works at: https://scholarlycommons.law.case.edu/swb

Part of the Human Rights Law Commons, and the Social and Behavioral Sciences Commons

\section{Recommended Citation}

Bond. 2009. "Reformist Reforms, Non-Reformist Reforms and Global Justice: Activist, NGO and Intellectual Challenges in the World Social Forum." Societies Without Borders 3 (1): 4-19.

Available at: https://scholarlycommons.law.case.edu/swb/vol3/iss1/2 


\title{
Reformist Reforms, Non-Reformist Reforms and Global Justice: Activist, NGO and Intellectual Challenges in the World Social Forum ${ }^{1}$
}

\author{
Patrick Bond \\ Centre for Civil Society, University of KwaZulu-Natal, South Africa
}

Keywords
World Social Forum, reformism, intellectuals, social movements, global governance

To fight for alternative solutions and for structural reforms (that is to say, for intermediate objectives) is not to fight for improvements in the capitalist system; it is rather to break it up, to restrict it, to create counter-powers which, instead of creating a new equilibrium, undermine its very foundations.

Andre Gorz, Strategy for Labor ${ }^{2}$

\section{Introduction: 'Foreign Policy Bottom Up'}

In South Africa, the merits of the World Social Forum (WSF) have been the subject of fierce debate. The difficulty experienced in establishing a

1) This article was partially presented as the author's inaugural professorial lecture in October 2007. Thanks are due staff/associates at CCS as well as other audiences who provided excellent feedback. Research and an initial presentation were supported by the United Nations Research Institute for Social Development and the Korean Research Foundation through its project with the Gyeongsang University Institute for Social Studies (KRF2005-005-J00201). Other publications with background arguments to this analysis include Bond 2005a on decommodification and deglobalization strategies; Bond 2005b and Bond 2007 on the promises and pitfalls of the World Social Forum as of early 2005 and mid2007 respectively; Bond 2006a on civil society mobilizations; Bond 2006b on problems with Millennium Development Goal campaigning; and Bond 2006c on the fruitless search for global governance reforms.

2) Gorz 1964. 
national affiliated social forum is just one reflection of ongoing strategic conflict. The 'Social Movements Indaba' network, established in 2002, is the closest to a gathering of independent left organizations approximating the WSF, and meets annually. Unfortunately, several logical constituencies organized labor, churches and health activists (in the Treatment Action Campaign) - have not been attracted to joining the Indaba, because its leading groups explicitly reject work within the ruling African National Congress and its Alliance with the Congress of SA Trade Unions and the SA Communist Party.

Meanwhile a few South African scholars are actively involved in WSF monitoring (most notably University of the Witwatersrand sociologist Jackie Cock). There are also several popular education institutes for progressive internationalist politics that contribute to the WSF, including Khanya College in Johannesburg, the Alternative Information and Development Centre and the International Labor Research and Information Group in Cape Town and in Durban, the Centre for Civil Society (CCS) at the University of KwaZulu-Natal. To elaborate on the latter (which I direct), CCS was established in mid-2001 with a primarily national focus. But from the outset, that mandate changed. Global networks are now crucial to CCS work, mainly because progressive actors in South African civil society themselves began not just thinking globally and acting locally, but also acting globally.

Who can forget the new century's initial global-focused protest, in August 2001 at the United Nations World Conference Against Racism in Durban, where more than 10,000 people marched against the UN because of the conference's shortcomings in relation to both Zionism and reparations for slavery, colonialism, neocolonialism and apartheid. Exactly a year later, activists again targeted the UN, at the World Summit on Sustainable Development in Johannesburg. South African civil society organizations witnessed elite managerial shortcomings for addressing poverty and environmental crises, and again demonstrated - bringing out 30,000 protesters - during a $12 \mathrm{~km}$ march from Alexandra township to the Sandton financial district. Over the subsequent two years, tens of thousands of civil society protesters attacked the Bush and Blair governments for their invasion of Iraq.

Much earlier, of course, civil society forces addressed the many ways that global injustices affect local organizing, here and everywhere. Beyond the highest-profile 19th and 20th century internationalist campaigns anti-slavery, the Spanish Civil War, anti-colonial solidarity (especially for 
Vietnam but also much of Southern Africa) - we began to understand how globalization compelled globally-coherent opposition, in the spirit of Karl Polanyi's 'double movement'. By the late 1990s, one of the main manifestations of neoliberalism in the Third World - two decades of 'IMF Riots', i.e., short, sharp reactions by oppressed people to international economic pressures - began transforming into mass opposition parties and movements.

Most famously, on 1 January 1994, the Zapatista movement spoke from an obscure region of southeastern Mexico about the suffering of Third World people when 'neoliberalism' (free market economic policies) accompanies longstanding political repression. The Zapatista guerrillas, peasants, liberation theologians and intellectuals successfully melded indigenous people's militancy and highly effective use of communication technologies. The result was widespread international resonance with Zapatismo's critique of the architectures of global power, making the people of Chiapas emblems of something much larger. At the end of 1999, the Seattle protest against the World Trade Organization was another critical rupture, putting elites everywhere on notice that democracy's global-scale deficits were no longer immune to society's critical gaze.

In Durban, at the same moment, what initially appeared as a purely municipal matter exploded into national and global consciousness: service delivery demonstrations. Today, these mark South Africa as the world's most protest-rich country, per capita. In 1999, investigations by the Durban Concerned Citizens Forum - headed by UKZN sociology professor emeritus Fatima Meer - into Chatsworth community grievances led to sustained mobilizations, analyzed by Ashwin Desai in his pathbreaking book We Are the Poors. ${ }^{3}$ The problems were soon articulated by grassroots activists in not merely local, but also national and also international terms. The education of Chatsworth and Durban as a whole culminated in a series of physical and court battles between the community and the municipality in early 2000 over evictions and water/electricity disconnections. (In 2007, Chatworth's Crossmoor community has taken center stage in resisting shack settlement evictions.)

In April 2000, the World Bank and International Monetary Fund held their spring meetings in Washington and 'two Trevors' - SA finance minister Manuel chairing the Board of Governors and Soweto community leader Ngwane teaching 30000 people to toyi-toyi in protest - were filmed

\footnotetext{
3) Desai 2002.
} 
by Ben Cashdan for SABC's Special Assignment (the film, Two Trevors go to Washington, is still a cult classic in the global justice community). ${ }^{4}$ The Jubilee SA movement that had begun a couple of years earlier moved to centre stage by bringing up the problem of apartheid debt, and the demand for reparations. (In 2003, at the bequest of US secretary of state Colin Powell, Mbeki's government sided with US corporations against Jubilee and the Khulumani Support Group in the New York courts. Though this led to the defeat of the reparations lawsuit, four years later, on appeal, a higher court ruled that the legal process should continue notwithstanding Pretorias sustained opposition.)

At the same time, president Mbeki unveiled himself as a dissident/denialist on AIDS, and the Treatment Action Campaign rose above fierce stigmatization and repression to humiliate him at the June 2000 international AIDS conference in Durban (TAC's comrades in ACT UP had done so a year earlier against a campaigning $\mathrm{Al}$ Gore, who until several protests changed his calculus, took millions from Big Pharma). The next month in Johannesburg, an international 'Urban Futures' conference sponsored by Wits University and the municipality - both facing intense protest by workers - allowed the newly-formed Anti-Privatization Forum to flower, for the conference acted as a magnet of unity against commodified education and municipal services. By 2001 the APF was waging war against the French company Suez, which by 2006 had had enough and left its once lucrative Johannesburg contract.

A Free Burma Campaign and Palestinian Support Committee also gathered strength during this period, with periodic protests at the Myanmar and Israeli embassies, often targeting South African hypocrisy for ongoing official relations with the two regimes. By 2007, when Pretoria authorized a UN Security Council vote in the Myanmar junta's favor, widespread national disgust was expressed, and later in the year, Gary Player was kicked out of Nelson Mandela's honorary golf tournament because he had designed a golf course in Burma (consistent with his previous pro-apartheid activities).

Environmental campaigning also developed during the late 1990s, as the post-apartheid government's ecological stewardship proved worse than apartheid's, i.e., more favorable to profits over people and planet. In nearly every category of threats to ecology - natural and social - this is well enough documented by even the government's own statistics. Some of the internationalist networks that emerged to fight state and capital focused

\footnotetext{
4) Available on the DVD set CCS WIRED, or from the filmmaker: ben@vukani.net.
} 
specifically upon hazardous chemicals (Thor mercury), occupational safety and health (especially asbestosis), nuclear energy, incineration, timber plantations and the petroleum industry. In Durban, by the mid-2000s, some of the strongest civil society linkages and solidarity relations were being forged by communities struggling with oil (South Durban Community Environmental Alliance and groundWork, e.g. with Nigerian and Ecuadorian anti-petroleum activists) and other toxins, and fighting carbon trading (Durban Group for Climate Justice).

Other Durban organizations with international allies include the famous street traders of whom more than 500 were arrested by rigid municipal police over petty by-law violations on a single day in June 2007 (one vehicle was the NGO Streetnet); shackdwellers (the highest profile of whom, in Abahlali baseMjondolo, had marches and protests regularly banned or repressed); municipal services activists (Chatsworth); fisherfolk subject to forced removal from the city's vast port in part due to US anti-terrorist provisions; and university academics (here at UKZN a 9-day strike in 2006 and ongoing freedom of expression issues receive global media coverage). Durban activists with connections to global networks also helped establish a strong critique of Mbeki's New Partnership for Africa's Development, which had a high-profile airing (and protest) at the launch of the African Union at the Durban International Convention Centre in mid-2002. Four years later at the same location, the International Sociological Association met many of the same organic intellectuals who interacted with academics at the organization's quadrennial congress, witnessing Desai's Wolpe lecture referred to below.

South African trade unions also regularly protested injustices on the regional and international stages, especially giving much-needed support to democratic and labor forces in Zimbabwe and Swaziland (the Mbeki government was partial to both repressive regimes). This was not necessarily easy during a period of rising working-class xenophobia and populist yellow-peril campaigning against East Asian goods. Labor internationalism was uneven, for during the late 1990s and early 2000s, some sections of the Congress of SA Trade Unions (Cosatu) also mistakenly endorsed the failed, protectionist 'Social Clause' concept within the framework of myopic World Trade Organization reform, and occasionally issues myopic global governance proposals. But generally Cosatu has maintained a progressive internationalist approach, finding common cause with oppressed peoples. Moreover, Cosatu and the SA Community Party regularly offer strong moral support to the Cuban, Bolivian and Venezuelan governments. 
These are just examples - not a comprehensive list - of how, dating to the turn of the 21st century, a 'foreign policy bottom-up' was established by progressive South Africans under difficult conditions. It is a most impressive group of social forces that call on their global-justice compatriots for assistance, as did the anti-apartheid movement to achieve sanctions, sports boycotts and solidaristic funding from the 1950s-1990s. One obvious point that unites many of the cases above, which we consider next, is the middle-class basis for many initial appeals to internationalist solidarity, as workers in NGOs (and to some extent universities) fire up the internet ether and make connections that in turn relate many of the base movements to each other in sectoral gatherings at sites like the WSF. But precisely that power and capacity require serious scrutiny so that they are not misused, as discussed below.

In some ways, the Mbeki government's 'talk left' strategy - raising Third World nationalist and even anti-imperialist grievances in speeches at major multilateral fora - has made solidarity more difficult (because like Robert Mugabe in Zimbabwe he has occasionally persuaded observers his rhetoric may match reality). But the 'walk right' that invariably followed outraged and mobilized activists every few months, and unveiled to the world's progressive activists how important it is to counter the South African ruling party's actual deeds.

The main missing process for these activists would have been a unifying agenda, in which a process such as the WSF - beginning in Porto Alegre in January 2001, continuing through to an Africa meeting in Nairobi in 2007 allowed many here and across the Third World to compare notes and develop strategy, sector-by-sector (for example, the 15 February 2003 antiwar mobilizations). We can return to this point to conclude.

However, before considering South African debates about a unifying WSF political program, CCS associates repeatedly ask whether those forces in global civil society striving for social justice have adopted appropriate analysis, strategies, tactics and alliances. Often we answer in the negative, as we assess the extent of democratization in the movements and whether they have put sufficient efforts into achieving 'non-reformist reforms', to borrow the distinction made by the late Andre Gorz in his 1964 book Strategy for Labor, as opposed to the 'reformist reforms' that are easier to justify to funders and mainstream allies but which do damage instead of good to the cause of social justice. (The latter include the Millennium Development Goals and Make Poverty History campaigns which adopt many of the presumptions of neoliberalism.) 
To demonstrate this, we can review some autocritical aspects of praxis - as progressive intellectuals and NGO strategists work with social movements (and their organic intellectuals) in struggles to shape the world - that appear relevant in our circuits today. With that as the base, we can briefly summarize the case against that group of world elites within political society who have entrusted themselves with the duty of global-scale reform, before considering the most recent round of failed reforms, some of which NGOs have uncritically joined. It is only after these exercises that a more durable approach to global social justice can be identified, mainly in the WSF.

\section{Intellectuals and NGOs in the Movement}

One issue discussed in detail at the Nairobi WSF in a vigorous Sociologists Without Borders 5 panel is how to line up the resources of formal academics properly within a social change agenda, to complement rather than negate progressive civil society experiences. This is rarely straightforward. Reflecting on CCS's own errors, scholar-activist Ashwin Desai expressed concern at the International Sociological Association meeting in 2006, when discussing work with social movements that are

militant and well rooted within poor communities. Ironically, the most visible of these movements are known not because of their militant interventions but because they have attracted to them supporters from a largely middle-class background who have broadly left-wing political commitments. In a phrase, they have attracted 'activists' who seek to come in from the bitter cold of the post-apartheid struggle landscape to the new fires that are burning in communities. These activists bring a range of important skills, perspectives and, most of all, resources to assist in the development, representation and generalization of these struggles. Celebratory academic papers are produced, books and newspaper articles are written, court cases fought, money for busses, meetings, rallies and T-shirts raised.

Unfortunately, these activists also bring with them certain infectious political diseases. Sometimes they are out to recruit members for their ultra-left sect or political party. Other times, as NGO workers who need to justify their existence, they insert themselves into struggles that may be written up in the next funding proposal. Still other times, one finds ambitious academics keen to distinguish themselves by getting the inside research track on some or other exotic rebellion, whose nuances they are best placed to enlighten their fellows in the academy about, while ratcheting up publication kudos. And, then lastly, one has the somewhat dated, free-floating, professional revolutionaries who genuinely believe they have something to add to these

5) Sociologists without Borders: http://sociologistswithoutborders.org/. 
struggles or, more accurately, that these struggles have something to add to the course of the battles they are already fighting. You see them attending marches, doing political education, writing letters and articles in the press or providing strategic advice to movements that often need assistance on the legal, logistical or financial fronts.

It is hard to think of any social movement that has lasted longer than six-months in South Africa that does not have quite an impressive support crew made up of the kinds of people I have just described. It is quite startling, then, that while social movements have been studied to death, those outsiders who play such a powerful role have largely escaped serious scrutiny... The actual constituency to which even the most radical academics are beholden are not the Poors. Nor is it the singular middle-class. Rather it is the mass of them gathered in conferences, journals, e-mail lists, universities and other sites of the production of bourgeois knowledge. ${ }^{6}$

Such concerns are regularly posed by South African activists, in part because of the tendency by academics to patronize and romanticize poor people and their movements (I am as guilty as anyone). Shannon Walsh - who as a CCS scholar was very active with several shackdweller communities - has described 'uncomfortable collaborations' between petit-bourgeois intellectuals and social movements:

Bertrand Russell traces the origins of the idea of a 'superior virtue of the oppressed' to a certain kind of paternalistic ideology developed by the Left during the French Revolution, remaining there ever since. The adulation for the oppressed, he argues, usually arrives via a hegemonic actor, one who may well be part of the subjugation of the very 'oppressed' he so admires... Russell is scathing in his analysis of how idealizing the oppressed is useful to the hegemonic classes, both to assuage guilt, but also to refuse the oppressed real power since it is their very subjection that makes them virtuous... Uncomfortable collaborations are one such space to see power at work in the everyday. To transform our notions of the Poor to active, desiring subjectivities means first to destroy the discourse that has been spun around them, yet also to acknowledge that without announcing it, many choose to mobilize these identities to stake claims for material, social and political gain from the state. This is part of how the friction between various forces can often open up the most unlikely spaces for change. ${ }^{7}$

Following Walsh, it is crucial for us all to more self-consciously assess from where the discourses we deploy emanate, particularly in view of the danger of paternalism. For internationalists concerned with strengthening 'civil society' ranging from grassroots movements to NGOs (the two particular types of groups I personally am most involved with), we have an important warning from Tanzanian legal scholar and political economist Issa Shivji:

\footnotetext{
6) Desai 2006.

7) Walsh 2007.
} 
As Amilcar Cabral, one of the foremost leaders of the African liberation movement, put it in his Weapon of Theory, 'every practice produces a theory, and that if it is true that a revolution can fail even though it be based on perfectly conceived theories, nobody has yet made a successful revolution without a revolutionary theory'. What is interesting about that period [1960s-70s] is that the radical intellectual discourse was integrated with militant activism; the two were mutually reinforcing.

The NGO discourse in the current period of apparent imperial 'triumphalism' eschews theory, emphasizes and privileges activism. In the African setting in particular, whatever is left of critical intellectual discourse, largely located at Universities, runs parallel to and is divorced from NGO activism. The requirements of funding agencies subtly discourage, if not exhibit outright hostility, to a historical and social theoretical understanding of development, poverty, discrimination etc. Our erstwhile benefactors now tell us, 'just act, don't think' and we shall fund both! ${ }^{8}$

Mike Davis has amplified the critique and applied it especially to urban NGOs in Third World cities, including those associated with World Bank projects. ${ }^{9}$ In the same spirit, James Petras and Henry Veltmeyer criticize NGO cadre who fail to properly address global power, for importing neoliberal precepts into social movements, dressing them up in the language of participation and consultation:

The effects of structural adjustment programmes and other [global] interventions have the potential of causing popular discontent. That is where the NGO's play an important function. They deflect popular discontent away from the powerful [global] institutions towards local micro-projects, apolitical 'grass roots' self-exploitation and 'popular education' that avoids class analysis of imperialism and capitalism. On the one hand they criticize dictatorships and human rights violations but on the other they compete with radical socio-political movements in an attempt to channel popular movements into collaborative relations with dominant neoliberal elites. ${ }^{10}$

The point to consider next, however, is that this Northern-influenced NGO cadre has done very poorly in recent years.

\section{From Reformist Reforms to Non-reformist Global Justice?}

For Naomi Klein, the period of global capitalist expansion since the 1970s is punctuated by crucial moments when, to quote Milton Friedman, advi-

\footnotetext{
8) Shivji 2006.

9) Davis 2006.

10) Petras and Veltmeyer 2002.
} 
sor to Augusto Pinochet after the 9/11/73 coup, 'only a crisis - actual or perceived - produces real change'. According to Klein:

[Friedman's pilot project] was the most extreme capitalist makeover ever attempted anywhere, and it became known as a 'Chicago School' revolution, as so many of Pinochet's economists had studied under Friedman there. Friedman coined a phrase for this painful tactic: economic 'shock treatment'. In the decades since, whenever governments have imposed sweeping free-market programs, the all-at-once shock treatment, or 'shock therapy', has been the method of choice. ${ }^{11}$

While the neoliberal project may have failed to meet its sponsors' promises, particularly in joining market freedoms with political liberty, nevertheless there is not yet a replacement conceptual framework strong enough to reshape the world. One reason is that a crucial middle ground exists where it appears a 'Post-Washington Consensus' ideology gives some hope to those shocked by neoliberalism. The idea here is to fix 'imperfect markets', add 'sustainable development' to the existing capitalist framework via UN and similar multilateral state-building efforts, promote a degree of global Keynesianism and oppose US unilateralism and militarism. Aside from UN agencies, Post-Washington Consensus advocates include large international NGOs (e.g., Care, Civicus, IUCN, Oxfam, TI), large environmental groups (e.g., Sierra, the World Wildlife Federation, Greenpeace and the World Conservation Union); big labour (e.g., ICTU and AFL-CIO), liberal foundations (Carnegie, Ford, MacArthur, Mott, Open Society, Rockefeller); the Socialist International, and a few governments (Norway, Italy). There are high-profile intellectuals, NGO leaders and especially rock stars associated with this current (Nancy Birdsall, Bono, Bernard Cassen, Peter Eigen, Bob Geldof, Anthony Giddens, Will Hutton, Paul Krugman, Kumi Naidoo, Dani Rodrik, Jeffrey Sachs, Amartya Sen, Nick Stern, Joseph Stiglitz).

But in recent years, global reforms promoted by the Post-Washington group have nearly invariably failed. Consider intra-elite battles decided

\footnotetext{
11) Klein 2007. Her other examples include the Malvinas war of 1982 between Argentina and Britain, China's Tiananmen Square in 1989, Eastern Europe during the 1990s, 9/11/01, the war on Iraq, the December 2004 tsunami, the August 2005 Katrina hurricane, as well as the happy shock we suffered in South Africa when in removing racial apartheid, the local and global elites brought us a more economically unequal version of class apartheid.
} 
mainly by the arrogance of the United States (US) and European Union $(\mathrm{EU})$ in recent years:

- in relation to geopolitical tension, the lack of peace settlements (or indeed prospects) in the Middle East, Gulf, central Asia, central Africa and the Horn of Africa, with a looming war involving the US, Iran and probably Israel and oft-predicted long-term inter-imperial conflicts between the US and China;

- on United Nations democratization, the inability to expand the Security Council in recent heads-of-state summits, notwithstanding pressure from aspirant members Japan, Germany, India, Brazil, Nigeria and South Africa;

- on trade, repeated delays in concluding the Doha Round of World Trade Organization (WTO) negotiations;

- in international finance, ongoing contagion of turbulence (including bursting market bubbles, bankruptcies and volatile currencies), extremely high - and growing - current account deficits in the US and other countries (including South Africa), World Bank legitimacy crisis, worsening IMF financial deficits, and US/EU resistance to Bretton Woods reform as witnessed by the leadership appointments in 2007 of two men from the neoconservative/neoliberal power structure, Robert Zoellick (World Bank) and Dominique Strauss-Kahn (IMF);

- environmentally, the failure of the EU and supportive Third World states to defend, much less expand the Kyoto Protocol, in part due to the 'carbon trading' distraction and in part due to the alternative alignment promoted by the US and Australian regimes, with Canada, China, India and South Africa joining, as large $\mathrm{CO}_{2} /$ per capita emitters lacking commitment to change production structures (with respect to other global ecological management problems arising in freshwater, maritime resources, trade in toxics, species extinction and the like, there has been very little or no progress); and

- an overall 'global apartheid' structure in terms of economics, political power, culture, public health and social services, through which most measures of inequality and genuine progress continue worsening, making mockery of the (already relatively unambitious) Millennium Development Goals (MDGs). ${ }^{12}$

\footnotetext{
12) www.redefiningprogress.org.
} 
According to South African president Thabo Mbeki, speaking at the September 2007 UN heads of state summit,

The cold reality is that it will be difficult for the UN in its present form fully to implement its own decisions and therefore help the poor achieve urgently the MDGs. Indeed, until the ideals of freedom, justice and equality characterize this premier world body, the dominant will forever dictate to the dominated and the interests of the dominated, which are those of the majority of humanity, would be deferred in perpetuity. ${ }^{13}$

Mbeki's pessimism is a tangible reflection of the lowered expectations the world elite really has for 'global governance' and world-scale reforms. Already in 2004, regretted cosmopolitan democracy champion David Held, 'The value of the UN system has been called into question, the legitimacy of the Security Council has been challenged, and the working practices of multilateral institutions have been eroded. ${ }^{34}$ These latter three points of Held are, indeed, celebrated by critics of imperialism, and after the UN General Assembly endorsed the US occupation of Iraq in May 2003, Tariq Ali suggested, simply, 'let it go the way of the League of Nations..$^{15}$

However, for many well-meaning intellectuals and NGO strategists, the danger of cooption has emerged in the so-called Post-Washington Consensus ideology, which often finds expression in campaigns such as the MDGs, Make Poverty History and the Global Call to Action against Poverty. These efforts rely for credibility upon minor advances within multilateral elite institutions. Activists associated with Post-Washington strategies are sometimes accused of promoting 'reformist reforms' which legitimize existing power structures, accumulation dynamics, and political processes, and which might also have the effect of demobilizing their own constituents by virtue of gaining a modicum of change on issues such as debt relief or aid promises. ${ }^{16}$ 'Non-reformist reforms,' in contrast, would open wide the doors for further contestation, would empower the movements not the system, and would identify areas of structural contradiction for more intense struggles ahead.

Reformist reformers include Make Poverty History strategists, unveiled in the British press as under the influence of Gordon Brown's office via the

\footnotetext{
13) Mbeki 2007.

14) Held 2004; rejoinders (including by me) can be found in Held 2005.

15) Ali 2003.

16) Bond, Brutus, and Setshedi 2005.
} 
Oxfam/Treasury/World Bank revolving door. ${ }^{17}$ At the end of 2005, writers like Stuart Hodkinson, Noreena Hertz and Maxine Frith analyzed the fatal flaws of Make Poverty History. According to Frith, the problem was that celebrities 'hijacked' the campaign. ${ }^{18}$ For Hertz, 'We achieved next to nothing' because 'the campaign's design allowed it to accept inappropriate markers for success that were never real proxies for justice, empowerment or accountability. And also because its demands were never in fact audacious enough. ${ }^{19}$ Hodkinson was even more critical:

By being too dependent on lobbying, celebrities and the media, by failing to give ownership of the campaign to southern hemisphere social movements, by watering down the demands agreed by grassroots movements at the World Social Forum, and by legitimizing the G8 summit, the campaign was doomed from the start. ${ }^{20}$

The idea was to provide relief from crushing debt loads, to double aid and to establish a 'development round' of trade. At best, partial critiques of imperial power emerged amidst the cacophony of all-white rock concerts and political grandstanding. At worst, polite public discourse tactfully avoided capital's blustering violence, from Nigeria's oil-soaked Delta to northeastern Congo's gold mines to Botswana’s diamond finds to Sudan's killing fields. Most of the London charity NGO strategies ensured that core issue areas - debt, aid, trade and investment - would be addressed in only the most superficial ways. By 2007, one of the main lobbyists, rock star Bob Geldof, finally became so frustrated that he called those attending the Heiligendamm G8 summit 'creeps' and their work a 'total farce'. ${ }^{21}$

Instead, a brighter future lies with those establishing non-reformist strategies that reject neoliberal precepts. At CCS we have seen four positions on how to not just reject but propose an alternative political framework. ${ }^{22}$ The debate was stimulated in July 2006 by the presence of Samir Amin, who was the key promoter of the 'Bamako Appeal', a document drafted five months earlier at the WSF in order to fuse socialism, antiracism/colonialism, and (national) development. The second position was an argument about 'Why Bamako does not appeal' by four CCS associ-

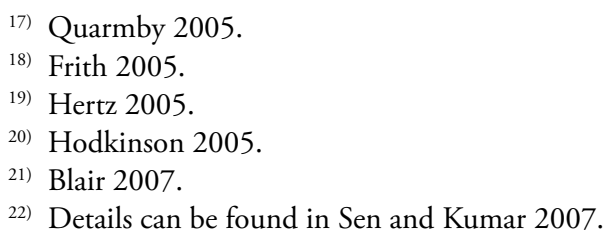


ates: Franco Barchiesi, Heinrich Bohmke, Prishani Naidoo and Ahmed Veriava. They accused the Appeal and the WSF of degenerating "into an organized network of experts, academics and NGO practitioners... The WSF elite's cold institutional and technicist soup, occasionally warmed up by some hints of tired poeticism, can provide little nourishment for local subjectivities whose daily responses to neoliberalism face more urgent needs to turn everyday survival into sustained confrontations with an increasingly repressive state." Third, another very strong tradition in the WSF is represented especially by the International Socialist tendency and Fourth International strand of Trotskyism, which see their role in the Forum movement as establishing socialist consciousness and cadre (as CCS associate Ngwane argues is needed).

A fourth position (which I am partial to) seeks the 21st century's anticapitalist 'manifesto' in the existing social, labor and environmental movements already engaged in excellent transnational social justice struggles. The WSF's greatest potential - so far unrealized - is the possibility of linking dozens of radical movements in various sectors. One of their struggles, the liberation of AIDS medicines from tyrannical monopoly patents which had previously prevented their consumption by poor people, has been sufficiently successful to claim both 'decommodification' and 'deglobalization' (of capital): these medicines are now free to low-income South Africans getting public health services (where those do exist) and are being produced by generic drug companies in several African sites. There are many other examples drawn from some of the finest networks of social justice activists presently active, in fields such as land (Via Campesino), healthcare (International Peoples Health Movement), free schooling (Global Campaign for Education), water (the People's World Water Forum), energy/ climate change (the Durban Declaration), debt (Jubilee South), and trade (Our World is Not for Sale).

The point, for those of us fortunate to study these movements, is not reification of everything poor people and their advocates do, especially given the kinds of conflicts - often unnecessarily ugly - that we in South Africa have seen emerge between advocates of the four political strategies suggested above. But it is to acknowledge that activists are driving the research forward in a manner that tells us more about the world than any other method, namely praxis in a non-reformist fashion. It behooves us to learn from their victories and failures, to both honor and lovingly criticize these comrades, if we want the most strongly rooted global justice program possible. 


\section{References}

Ali, T. 2003, 'Business as Usual,' The Guardian, 24 May 2003.

Blair, D. 2007, 'Geldof and Bono Blast G8 for Betraying Africa', Telegraph, 9 June.

Bond, P. 2005a, 'Globalisation/Commodification or Deglobalisation/Decommodification in Urban South Africa', Policy Studies, 26, 3: 337-358.

Bond, P. 2005b, 'Gramsci, Polanyi and Impressions from Africa on the Social Forum Phenomenon', International Journal of Urban and Regional Research, 29, 2: 433-440.

Bond, P. 2006a, 'Civil Society on Global Governance: Facing up to Divergent Analysis, Strategy and Tactics', Voluntas, 17, 4: 359-371.

Bond, P. 2006b, 'Global Governance Campaigning and MDGs: From Top-down to Bottom-up Anti-poverty Work', Third World Quarterly, 27, 2: 339-354.

Bond, P. 2006c, Talk Left, Walk Right: South Africa's Frustrated Global Reforms, Pietermaritzburg, University of KwaZulu-Natal Press.

Bond, P. 2007, 'Linking Below, Across and Against: World Social Forum Weaknesses, Global Governance Gaps, and the Global Justice Movement's Strategic Dilemmas', Development Dialogue, 49: 83-98.

Bond, P., D. Brutus, and V. Setshedi 2005, 'Are Mainstream NGOs Failing Africa?', ZNet Commentary, 21 June; and 'When Wearing White Is Not Chic, and Collaboration Not Cool', Foreign Policy in Focus, 17 June.

Davis, M. 2006, Planet of Slums, London: Verso.

Desai, A. 2002, We Are the Poors, New York: Monthly Review Press.

Desai, A. 2006, 'Vans, Autos, Kombis and the Drivers of Social Movements', Harold Wolpe Lecture, University of KwaZulu-Natal Centre for Civil Society and International Sociological Association, Durban, 28 July.

Frith, M. 2005, 'Celebrities "Hijacked” Poverty Campaign, Say Furious Charities', The Independent, 27 December.

Gorz, A. 1964, A Strategy for Labor, Boston: Beacon Press.

Held, D. 2004 'Globalization: The Dangers and the Answers', openDemocracy, www. opendemocracy.net/globalization-vision_reflections/article_1918.jsp.

Held, D. 2005, Debating Globalization, Cambridge: Polity Press.

Hertz, N. 2005, 'We Achieved Next to Nothing', New Statesman, 12 December.

Hodkinson, S. 2005, 'G8, Africa Nil', Red Pepper, 27 October.

Klein, N. 2007, The Shock Doctrine: The Rise of Disaster Capitalism, London: Penguin.

Mbeki, T. 2007, 'Address by President of South Africa, Thabo Mbeki, at the 62nd session of the United Nations' General Assembly', New York, 25 September, http://www. info.gov.za/speeches/2007/07092610451002.htm.

Petras, J. and H. Veltmeyer 2002, Globalization Unmasked, London: Zed Books.

Quarmby, K. 2005, 'Is Oxfam Failing Africa?', New Statesman, 30 May.

Sen, J. and M. Kumar 2007, A Political Programme for the World Social Forum? Democracy, Substance and Debate in the Bamako Appeal and the Global Justice Movements, New Delhi, Institute for Critical Action - Centre in Movement and Durban, Centre for Civil Society, http://www.nu.ac.za/ccs/files/CACIM\%20CCS\%20WSF\%20Politics. pdf. 
Shivji, I. 2006, 'The Silences in the NGO Discourse: The Role and Future of NGOs in Africa', Keynote Paper presented to the Symposium on NGOs, Arusha, Tanzania, 28 November.

Walsh, S. 2007, 'Uncomfortable Collaborations: Contesting Constructions of the Poor in South Africa', Paper presented to the SANPAD Poverty Challenge Conference, Durban, 27 June. 
Copyright of Societies Without Borders is the property of Brill Academic Publishers and its content may not be copied or emailed to multiple sites or posted to a listserv without the copyright holder's express written permission. However, users may print, download, or email articles for individual use. 